УДК [821.161.1+821.161.2].091

\title{
BORIS POPLAVSKY AND EUGENIY MALANIUK: TYPOLOGY OF EXPATRIATION AS AN ASPECT OF CULTURAL ALLOTROPY
}

\author{
Ольга В’ячеславівна Червінська \\ orcid.org/0000-0001-9261-0604 \\ o.chervinska@chnu.edu.ua
}

Доктор філологічних наук, професор, завідуюча кафедрою

Кафедра зарубіжної літератури та теорії літератури

Чернівецький національний університет імені Юрія Федьковича

Вул. Коцюбинського, 2, 58012, м. Чернівці, Україна

\section{Юлія Юріївна Вільчанська \\ lusjen77@mail.ru \\ Здобувач}

Кафедра зарубіжної літератури та теорії літератури Чернівецький національний університет імені Юрія Федьковича Вул. Коцюбинського, 2, 58012, м. Чернівці, Україна

Анотація. Екзистенційні акценти екзилю - не цілком сфокусований об'єкт. Існують фактори в історії культур, які легше зрозуміти, виходячи з актуальної дійсності: присутність певної культури в іншій культурній структурі, коли творча особистість стоїть перед необхідністю самоідентифікації У культурологічному аспекті будь-яка з умовно однорідних культур (або, підхоплюючи вираз П. Сорокіна - „соціокультурних тіл”) в контекстах свого розвитку неминуче стикалася, стикається або ще зіткнеться в майбутньому з ситуацією, коли ця однорідність перестає бути очевидною. Зокрема, досвід розпаду цілісної, на перший погляд, культури Російської імперії, дає дуже показові приклади, пов’язані з фактором так зв. алотропії (поняття практично відсутнє в літературознавчому лексиконі, хоча цілком доречно озброїтися цим старовинним науковим терміном, що містить відомі

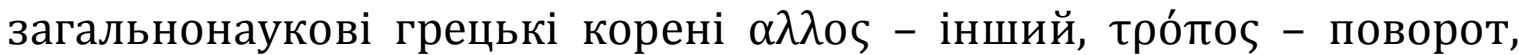
властивість). Йдеться про ті різноманітні форми, в які вилилося існування представників окремих національних культур Росії після Жовтневого перевороту, і які генерували виникнення різних, відомих на сьогодні діаспор - таких, наприклад, як вірменська,

(C) Червінська О., Вільчанська Ю. 2016 
російська, українська та ін. На позначеному синхронічному зрізі представляє інтерес період становлення таких діаспор (перша хвиля еміграції), головним пунктом якого стає генерування відповідного ідеологічного стрижня. У цьому сенсі цікаво простежити типологічні зразки на найбільш показових прикладах. Розглядається творчість двох поетів-емігрантів: Бориса Поплавського (російська діаспора) і Євгена Маланюка (українська діаспора). Йдеться про типологічно полярні трансформації біографічного досвіду в перспективі ідеології діаспори.

Ключові слова: фактор алотропії, діаспора, експатріація, поети-емігранти, екзиль, Борис Поплавський, Євген Маланюк.

Although exile existential emphases are not considered to be a completely focused object, the problem itself has ancient roots in the culture; we can find it reflected even in the Bible, so we are talking about the presence of well-defined cultural entities in different cultural fields. In the culture study aspect anyone of conventionally homogeneous cultures (or using the expression by Sorokin - "socio-cultural bodies") in the context of its development inevitably faces, or will face in future, with a situation where the homogeneity ceases to be obvious because of the presence of quite alien intrusions in it. This creates a situation where a person, for any reasons "transplanted" into an alien world, faces the necessity of identity and manifests himself/herself accordingly.

In this regard, there are factors in the history of cultures which are easier understood when based on the current reality (as motivated in the philosophical platform of Julia Kristeva, i.e. in the essay "Strangers to Ourselves" (1988). In particular, the experience of integral culture collapse of the Russian Empire, at first glance, gives very significant examples related to the so-called allotropy factor (the literary lexicon virtually lacks the concept, although it is appropriate to use this ancient scientific term containing commonly known Greek roots $\alpha \lambda \lambda \mathrm{o} \varsigma_{-}$ other, $\tau \rho$ ó $\pi$ o $\varsigma$ - feature).

In general, allotropy can be interpreted by means of the metaphor inherent in chemical stability in all versions of its form ("a cloud, a dewdrop, an iceberg" - all are forms of certain substances which are the essences of a single entity). In historical time the presence of allotropes, the congruence of the overall variability of them, the most reliably preserve the tradition. In terms of culture study, this situation is specified by "the environment" - by the context, which is regarded as actually alien environment, and it doesn't matter if "the stranger / outsider" likes 
it or not, he/she has to react and to take it into account. On this basis, allotropy appears to be the essential argument of upgrading the traditional form. However, it can manifest itself at various levels, where there are both "common denominators" and, at the same time, in terms of methodological perspective - "diverse reference points of the text strategy" (T. Bovsunivska's expression).

We mean typologically polar transformations of biographical experience in the Diaspora ideology outlook, the various forms which presented the existence of representatives of individual national cultures of Russia after the October Revolution generating the emergence of various known today diasporas - such as the Armenian, Russian, Ukrainian and others.

Experience comparison of Poplavsky B. (1901-1936) and Malaniuk E. (1897-1968) - essentially is an example taken at random. Of the many names that have proved to be impressive in that period, these names, at first glance, do not connote each other. At least none of their researchers do not compare these figures, the more interesting to try.

Both these poets belong to the same period and the same country which they left after the October Revolution, they both were writers in exile, but the first one committed suicide (some researchers admit that it was not planned and random), while the second died a natural death on the way to the theatre, being American retiree and at the same time an active promoter of the national idea in the Ukrainian Diaspora. Yet the comparison of the two, such fully diverse poets as B. Poplavsky and E. Malaniuk, is not so ironic considering their influence and common key points as for the biographies of former compatriots (the subjects of the Russian Empire) and actual age-mates: their escape from the Bolshevik reality (both - in 1920), and then the inevitable implication in a different society. There is every reason to consider this point the common denominator of the exile typology in general.

These artists come closer in typological unswerving devotion to their own national culture, their poetic mission, in common logic of the exile theme, in modernist context of their own practice of poetry writing. This is indicated by the comparative analysis of their heritage (the attraction to refined metaphors, their devotion to the Christian outlook, the transitive theme of death, etc.). However, in this instance, the controversy is more evident than the defined typological approach. The differences include language, cultural and linguistic contexts of alien 
land, social withdrawal of Poplavsky in spite of social activity of Malaniuk, the immutability of "the place" (Paris), personal isolation and the loneliness of one as opposed to some family experience as well as "transitions and outcomes" of another etc. That is, the biography of each appears to be the evident controversy with the respect to the other. In addition, Poplavsky had no such attention and recognition among his fellow exiles, as Malaniuk had in the circles of the Ukrainian Diaspora. Finally, the talent of B. Poplavsky did not have time to reveal itself on the same scale as the talent of the Ukrainian poet, who was lucky enough to publish a dozen books of poetry at the time of his expatriation. And, nevertheless, the argument for the comparison is, above all, their citizenship origin, their doubtless thematic syntony and comparability of their poetic skill.

The common homeland, abandoned by them, was a very peculiar topos. By extant documentary evidence (involving the memories of the period contemporaries) the intellectuals' euphoric state of three capitals of those days Russia - St. Petersburg, Moscow, Kyiv - during the first months of the Soviet regime had not yet cultivated the national idea with obvious political emphasis, as reflected in the following years and outside the country, since in the experience of many representatives of Russian culture both Kyiv and other cities of eastern and central Ukraine had played an equal role (primarily let's mention N. Berdyaev, A. Block, K. Paustovsky, N. Anciferov, M. Bulgakov, A. Kuprin, M. Aldanov, Yu. Terapiano, I. Stravinsky and most Acmeists).

At the same time the future active supporters of the Ukrainian national idea were directly related to the culture of St. Petersburg (in particular E. Malaniuk studied at St. Petersburg Polytechnic Institute). From the memories of Galina Zhurba ("From "Ukrainian peasant house" to "Musagit": People and Events") and Klim Polishchuk ("From the revolution vortex: Fragments of the memoirs about literary Kyiv in 1919") you can see the true face of the original "cultural syncretism". Galina Zhurba wrote rather bright and eloquent memory of Kyiv bohemian tradition of the time: "In evenings we gathered in "One-eyed Jim" - the club - coffee shop - canteen, where bohemia came: MoscowJew and ours <...>. In "One-eyed Jim" authors recite their poetry. Russians started. Then spoke ours - Yaroshenko, or Klim Polishchuk". By the way, Klim Polishchuk who fell victim of repression in 1937, in his memoirs about the literary Kyiv in 1919 also noted that all the literary circles, in all their originality, sought to work together (in the 
depths of which, however, a strong national feeling matured and grew) (the memories were published as attachment to the article by Lysenko) [3].

"It's easy for some "critic" from the Smotrich banks - he wrote quite ardently - to slate M. Semenko's first "futurisa" $<\ldots>$, but let them try to create something consolidating like that, which would involve "the right", "the left" and, at the same time wouldn't disorder the integrity of all creative powers ideological unity.

"Art/Мистецтво" - Ukrainian, "Dawns/Зори" - Russian, "Baginen" - Jewish, all published under the brand name "All Ukrainian Literary Committee/Всеукрлитком", will be a valuable material for a literary historian whishing to highlight our age and to show our grandchildren the enthusiasm of our unsteadily faith, which has left us at the parting of the ways. The future historian will narrate about the conditions in which everything was done then, how hard it was to fight for what belongs by right; about a handful of hungry young artists working hard in those days, while "Coryphaei" sang "Urban Keller" at "Merry tables" of Viennese coffee houses".

Today it is important in a new way to listen to the words of Klim Polishchuk, who in fact echoed Alexander Blok's idea as about the attempts of artists who then sought to "serve one god (referring to art. O. Ch. and Y. V.); so it's a pity that it remained only an attempt, albeit interesting one" [3, p. 23]. Later, however, this desire for unity, explicable by common ground with its loss turns into something opposite. In this synchronic time span the formation of the various "postimperial" Diasporas (the first wave of emigration) is of great interest. His main point becomes a creation of the corresponding ideological clamp.

The creative activity of these two poets-emigrants here in some way tapers the typology. For the Russian Diaspora the case of Boris Poplavsky was fairly typical, sometimes he is referred to as "the spokesman of the collective spirit": the general background was a feeling of a catastrophic collapse of the great culture, the irreversibility of the situation and the activated paradigm of the "past". At the same time, the Ukrainian Diaspora intensified the paradigm of the "future" and linked it with the original idea of the independence of the Ukrainian culture and the optimistic dream of the Ukrainian state (of course, in this respect there was not any thought of a suicide). In our opinion, it is precisely the fact that explains that dissociation of the Russian emigration quite reasonably contrasted with the unity of the Ukrainian Diaspora. The 
problem of existence in this case acquires the value of the most important criterion. So, J.-P. Sartre stressed: "We must make people understand that only the reality matters; that dreams, expectations and hopes make it possible to determine a person only as a deceptive dream, as collapsed hopes, as vain, to define a person negatively, not positively. However, when they say: "You are nothing but your life" it does not mean that, for example, the artist will be judged only by his works; there are thousands of other things that define him" [9, p. 333-334].

As opposed to B. Poplavsky and contrary to the aggregate of many motives, objectively approaching to his tragic lyric poetry Malaniuk, this Ukrainian poet was saved from suicide by the community of ideological confrontation to the reality inherent in the Ukrainian Diaspora. Although at the beginning of the emigrant experience undergoing the survival in a foreign culture he contemplated suicide (for example, as known for the unrequited love to N. Levitska-Kholodna).

It is necessary to note that "strangeness" [1] is one of the main concepts in the study of exile interpretation. In the texts of E. Malaniuk we see a clear distinction between "native" and "alien":

Там свист херсонського простору!

Там вітер з кришталевих хвиль!

А тут: в вікні опустиш штору -

I п’єш, самотній, смертний біль [4, p. 69].

J. Kristeva gives characteristics of different types of "strangers" such as "alien" trying to survive, turning to the lost land of his tears, "a melancholic lover of lost space, he is, in fact, inconsolable because once he left it" [2, p. 17]. In the notebook of E. Malaniuk (for 3-4.02.40) we read of the coveted return there, "where Mom, Grand-dad, Granny, Father, old wicket and old porch will welcome. July day, the flowerbed is sweet-smelling. They all are dressed in festive. "At last he came, we have been waiting for". There are glorioles above their heads (or maybe just the sun) - this is the only supernatural. And also it had to be - the death. Turn to childhood, family, home and birth. It is getting dark. I know - it will be only at the dying hour" [5, p. 67].

By means of a similar situation J. Kristeva explains how a "feeling of rancour against others" appears in a stranger. As she writes:

"Lost Paradise - is a mirage of the past, which can not be regained. He (the stranger. - O. Ch. and Y. V.) knows that by some sad awareness 
that turns his rancour against others (because there is always someone else, evil reason for his exile) against himself: "How could I leave them? I left myself' [2, p. 17].

B. Poplavsky has different perception of the world, in his case historic interception helps to aggravate the feelings of the "balance loss". In his diary (01.01.1921) eighteen-year-old poet describes the sacredness of the time conscious by him: "This is a terrible time. I have found an amazing point in the Bible: this period will be terrible for Jacob, but he will find his salvation in it. I admit: some years are like a hundred" (8, p. 22). A morbid worldview of Poplavsky became even more vulnerable in exile, gradually turning into a spiritual illness. His texts lack happy memories of the past or any hope for the future. Doom for him is a statement of fact:

Смерть нас розовым солнцем ждет
Мы возлюбили её вполне
Мы изменили родной стране
Мы целовали ее в чело
И миновали добро и зло [7, p. 100].

Кружась не замечали, не смеялись,

Не узнавали, умирая, дом.

Мы никогда назад не возвращались,

Хоть каждый день ко флигелю идем [7, p. 104].

And the same theme somehow varies in another poem:

Безмерно удивлялись: разве это

Та родина, которая? та? ту?

Но уходило прочь земное лето.

Валилось сердце в смертную пяту [7, p. 104].

Some stable (explicit or latent) compositional factors are presented in every temporal "frame" at the level of causal innovations, and the following requires appreciation: localized remainder of Another, which at the same time appears (or does not appear) as the Other. The existence fermented with so conditional and rather vague term as the mentality does not always actualize in one-dimensional culturological topos. Any Russian, Ukrainian, Jewish, Italian, Polish, Chinese, Arab or another representative of the people) can live outside the native country, retaining his ideological presence in the nation, that is, he remains one of 
its "allotropic" forms. The Ukrainian version of such a situation is clearly marked by Solomia Pavlychko in her analysis of the two polarities of the Ukrainian poetic tradition in emigrant circles of America and in particular New York of 60-70s (so-called NYG and the journal "Kyiv"):

We can assume that the founders of published in America journal "Kyiv" by its title wanted to say: wherever we are, we remain the community of Kyiv, Ukrainians, we cultivate our Ukrainian conscience, and consider Kyiv to be the capital of Ukrainian literature with all the consequences. Thus, "Kyiv" is an oasis of "native" in other alien lands, not having any connection to them.

The New York Group set opposite task, i. e. openness to the world, integration with cultures speaking other languages [6, p. 383].

Thus, the exile situation, with all the typological proximity of the poetic experience of different culture representatives, with all similar types of consciousness that it produces and, respectively, the range of themes, motifs, and even techniques, nevertheless suggests allotropes if cultural formula in each case will retain its own immanent quality. In fact, many (even not considered here) examples show that the value of the language is not so essential.

1. Дзик Р. А. Теоретико-художнє осмислення екзилю Юлією Крістевою / Р. А. Дзик // Питання літературознавства. - 2013. - № 88. - С. 69-88.

2. Крістева Ю. Самі собі чужі / Юлія Крістева ; [пер. 3 фр. З. Борисюк]. К. : Вид-во Соломії Павличко „Основи”, 2004. - 262 с.

3. Лисенко $H$. „Схопить момент переходу...” / Н. Лисенко // Книжник. 1992. - № 2. - С. 18-23.

4. Маланюк 6 . Вибрані твори / Є. Маланюк. - Харків : Ранок, 2009. $288 \mathrm{c}$.

5. Маланюк $\epsilon$. Нотатники (1936-1968) : документально-художнє видання / Є. Маланюк. - К. : Темпора, 2008. - 336 c.

6. Павличко C. Модерністичний рух на заході в 60-70-і роки (Ньюйоркська група) / С. Павличко // Теорія літератури. - К. : Вид-во Соломії Павличко „Основи”, 2002. - С. 381-418.

7. Поплавский Б. Орфей в аду: Неизвестные поэмы, стихотворения и рисунки / Б. Поплавский. - М. : Гилея, 2009. - 191 с.

8. Поплавский Б. (1903-1935) Метафизический граммофон : [дневник] / Б. Поплавский. - СПб. : ООО Леонардо, 2010. - 192 с.

9. Сартр Ж.-П. Экзистенциализм - это гуманизм / Жан-Поль Сартр // Сумерки богов. - М. : Политиздат, 1990. - С. 319-344. 


\title{
БОРИС ПОПЛАВСКИЙ И ЕВГЕНИЙ МАЛАНЮК: ТИПОЛОГИЯ ИЗГНАННИЧЕСТВА В АСПЕКТЕ КУЛЬТУРНОЙ АЛЛОТРОПИИ
}

\author{
Ольга Вячеславовна Червинская \\ orcid.org/0000-0001-9261-0604 \\ o.chervinska@chnu.edu.ua
}

Доктор филологических наук, профессор, заведующая кафедрой

Кафедра зарубежной литературы и теории литературы

Черновицкий национальный университет имени Юрия Федьковича

Ул. Коиюбинского, 2, 58012, г. Черновцы, Украина

\section{Юлия Юрьевна Вильчанская \\ lusjen77@mail.ru \\ Соискатель}

Кафедра зарубежной литературы и теории литературы

Черновицкий национальный университет имени Юрия Федьковича

Ул. Кочюбинского, 2, 58012, г. Черновиы, Украина

Аннотация. Экзистенциальные акценты экзиля представляют собой не вполне сфокусированный объект. Существуют факторы в истории культур, которые легче понять, исходя из актуальной действительности: присутствие определенной культуры в иной культурной структуре, когда творческая личность стоит перед необходимостью самоидентификации. В культурологическом аспекте любая из условно однородных культур (или, подхватывая выражение П. Сорокина - „социокультурных тел”) в контекстах своего развития неизбежно сталкивалась, сталкивается или еще столкнется в будущем с ситуацией, когда эта однородность перестает быть очевидной. В частности, опыт распада целостной, на первый взгляд, культуры Российской империи, дает очень показательные примеры, связанные с фактором так наз. аллотропии (понятие практически отсутствует в литературоведческом лексиконе, хотя вполне уместно вооружиться этим старинным научным термином, содержащем известные общенаучные греческие корни $\alpha \lambda \lambda$ о -

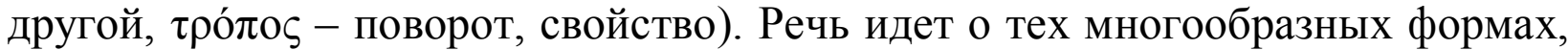
в которые вылилось существование представителей отдельных национальных культур России после Октябрьского переворота, и которые генерировали возникновение различных, известных на сегодня диаспор - таких, например, как армянская, русская, украинская и пр. На обозначенном синхроническом срезе представляет интерес период становления таких диаспор (первая волна эмиграции), главным пунктом которого становится генерирование соответствующей идеологической крепы. В этом смысле интересно проследить типологические образцы на наиболее показательных примерах. Рассматривается творчество двух поэтов-эмигрантов: Бориса Поплавского (русская диаспора) и Евгения Маланюка (украинская диаспора). Речь идет о 
типологически полярных трансформациях биографического опыта в перспективе идеологии диаспоры.

Ключевые слова: фактор аллотропии, диаспора, экспатриация, поэтыэмигранты, экзиль, Борис Поплавский, Евгений Маланюк.

\title{
BORIS POPLAVSKY AND EUGENIY MALANIUK: TYPOLOGY OF EXPATRIATION AS AN ASPECT OF CULTURAL ALLOTROPY
}

\author{
Olha Chervinska \\ orcid.org/0000-0001-9261-0604 \\ o.chervinska@chnu.edu.ua
}

The Department of World Literature and Theory of Literature

Yuriy Fedkovych Chernivtsi National University

2, Kotsiubynsky St., 58012, Chernivtsi, Ukraine

Yulia Vilchanska

lusjen77@mail.ru

The Department of World Literature and Theory of Literature

Yuriy Fedkovych Chernivtsi National University

2, Kotsiubynsky St., 58012, Chernivtsi, Ukraine

\begin{abstract}
Exile existential accents are not considered to be a completely focused object. There are factors in history of cultures which are easier for understanding, proceeding from the current reality: the presence of certain culture in other cultural structure when the creative person faces an indispensability of selfidentification (as motivated in the philosophical platform of Julia Kristeva, i. e. in the essay "Strangers to Ourselves" (1988). In the culture study aspect anyone of conventionally homogeneous cultures (or using the expression by Sorokin - "sociocultural bodies") in the context of its development inevitably faces, or will face in future, with a situation where the homogeneity ceases to be obvious.

In particular, the experience of integral culture collapse of the Russian Empire, at first glance, gives very significant examples related to the so-called allotropy factor (the literary lexicon virtually lacks the concept, although it is appropriate to use this ancient scientific term containing commonly known Greek

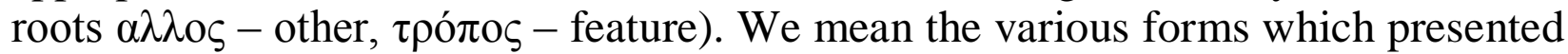
the existence of representatives of individual national cultures of Russia after the October Revolution generating the emergence of various known today diasporas such as the Armenian, Russian, Ukrainian and others. In this synchronic time span the formation of the various "post-imperial" Diasporas (the first wave of emigration) is of great interest. Their main point becomes a creation of the corresponding ideological clamp. In this respect it is interesting to trace typological samples on the most revealing examples.

The given article examines the work of two poets-emigrés: Boris Poplavsky (Russian diaspora) and Eugeniy Malaniuk (Ukrainian diaspora). It is a question of
\end{abstract}


typologically polar transformations of biographical experience in the Diaspora ideology outlook.

Key words: allotropy factor, diaspora, expatriation, poets-emigrés, exile, Boris Poplavsky, Eugeniy Malaniuk.

\section{References}

1. Dzyk R. Teoretyko-khudozhnie osmyslennia ekzyliu Iuliieiu Kristevoiu [Theoretical and Methodological Comprehension of the Exile by Julia Kristeva]. Pytannia literaturoznavstva, no. 88, pp. 69-88.

2. Kristeva J. Sami sobi chuzhi [Strangers to Ourselves]. Kyiv, 2004, 262 p.

3. Lysenko N. "Skhopyt" moment perekhodu..." [Grab a Moment of Transition]. Knyzhnyk, no. 2, pp. 18-23.

4. Malaniuk E. Vybrani tvory [Selected works]. Kharkiv, 2009, 288 p.

5. Malaniuk E. Notatnyky (1936-1968): Dokumental'no-khudozhnie vydannia [Notebooks (1936-1968): documentaries and artistic publications]. Kyiv, 2008, $336 \mathrm{p}$.

6. Pavlychko S. Modernistychnyi rukh na zakhodi v 60-70-i roky (N'iu-iorks'ka hrupa) [Modernist movement in the West at 60-70 years (New York Group]. In: Theory of Literature. Kyiv, 2002, pp. 381-418.

7. Poplavsky B. Orfei $v$ adu. Neizvestnye poemy, stikhotvoreniia $i$ risunki [Orpheus in the Underworld. Unknown Poems, Poems and Drawings]. Moscow, 2009, $191 \mathrm{p}$.

8. Poplavsky B. (1903-1935) Metafizicheskii grammofon: (dnevnik) [Metaphysical gramophone: (a dairy)]. Saint Petersburg, 2010, 192 p.

9. Sartre J.-P. Ekzistentsializm - eto gumanizm [Existentialism is a Humanism]. In: Sumerki bogov. Moscow, 1990, pp. 319-344.

\section{Suggested citation}

Chervinska O., Vilchanska Y. Boris Poplavsky and Eugeniy Malaniuk: typology of expatriation as an aspect of cultural allotropy. Pytannia literaturoznavstva, 2016, no. 94, pp. 215-225.

Стаття прийнята до друку 20.11.2016 р. 